\title{
Prevalence and intensity of Ixodidae in cattle, goats and sheep brought to the municipal slaughterhouse of Tadjenanet, in Mila, north-eastern Algeria
}

Derradj Lotfi ( $\square$ lotfi.derradje@umc.edu.dz)

University of Constantine https://orcid.org/0000-0001-8751-6568

Kohil Karima

University of Constantine

\section{Research Article}

Keywords: Prevalence, Ixodidae, Sheep, Abattoir, Mila, Algeria

Posted Date: April 6th, 2021

DOl: https://doi.org/10.21203/rs.3.rs-397597/v1

License: (c) (i) This work is licensed under a Creative Commons Attribution 4.0 International License.

Read Full License 


\section{Abstract}

A four-month survey was carried out to study the prevalence, intensity and ecological indices of Ixodidae on cattle, goats and sheep brought to the slaughterhouse in the municipality of Tadjenanet, in northeastern Algeria. Of the 447 animals examined, 67 (14.96\%) were infested by one or more ticks. A total of 262 ticks were collected and ten species grouped under two genera were inventoried: Rhipicephalus spp. (79.77\%) and Hyalomma spp. (20.23\%). The tick spicies collected included Hyalomma anatolicum, Hyalomma excavatum, Hyalomma impeltatum, Hyalomma lusitanicum, Hyalomma marginatum, Hyalomma scupence, Rhipicephalus (Boophilus) annulatus Rhipicephalus bursa, Rhipicephalus turanicus and Rhipicephalus sanguineus. This is the first time that Hyalomma impeltatum have been reported in Mila region. The most abundant species was Rhipicephalus bursa (41.22\%). The presence of Hyalomma impeltatum in the study area was an interesting finding. The present study provides basic data on the status of the parasite in the province of Mila.

\section{Introduction}

Ticks with hematophagous behaviour are the major problem in livestock, as they are capable of transmitting a wide variety of pathogens. Worldwide, there are more than 900 species of ticks, of which more than $79 \%$ are hard ticks (Bowman, 2008). Ticks can play an important role as reservoirs of bacteria, parasites, and virus in nature (Parola \& Raoult, 2001). In Algeria, only a few papers have documented the different aspects of ticks infesting domestic animals (Boulkaboul, 2003; Yousfi Monod \& Aeschlimann, 1986; Benchikh et al., 2007, 2013, 2017, 2019; Derradj and Kohil, 2020). Researchers in Algeria have identified 14 species and subspecies of Ixodidae (Walker et al., 2003).

However, most of the previous studies did not take into account the biodiversity of the tick fauna of northeastern Algeria and the comparison between the different categories of animals (Cattle, sheep, and goats) has not been fully studied to treat and control them appropriately. The key to disease control programmes must be based on a sound knowledge of the regional phenology of ticks and the epidemiology of the infections they transmit (Benchikh et al., 2013). Based on the approach presented in Benchikh et al. (2013), in this paper the authors provide an overview of the biodiversity of the hard tick fauna. The aim was to determine and compare the prevalence and intensity of infestations on domestic animals in the municipal slaughterhouse of Tadjenanet, province of Mila, north-eastern Algeria.

\section{Materials And Methods}

\section{Study area}

The province of Mila is a semi-arid region; summers are hot and dry and winters are cold and humid (Figure 1).

\section{Animals and collection of ticks}


From May (last month of spring) June, July, and August (Summer) 2020, a total number of 447 animals, cattle $(n=70)$, goats $(n=196)$ and sheep $(n=181)$ of different age groups, breeds and sexes were considered in this study. Information about the animals and the location of ticks was collected from each animal. The animals were examined carefully and the ticks were collected in labelled vials containing $70 \%$ ethanol. The ticks were identified under the stereomicroscope using the key of Walker et al. (2003).

\section{Statistical analysis}

All data were exported to an Excel $\circledast$ spreadsheet for Windows ${ }^{\circledR}$ to estimate species frequency, infestation prevalence and intensity averages for females, males in livestock, epidemiological indicators: prevalence and intensity (Bush et al. 1997) as follows:

Infestation prevalence (percentage) $=100 \times$ (number of infested animals /number of examined animals)

Tick infestation intensity $=$ the number of ticks/the number of infected animals

The chi-square test was used to compare prevalences, while comparisons of tick infestation intensities and attachment sites were made using the ANOVA test with a cut-off value of 0.05 for both tests (Schwartz, 1993). The PAST test was used to calculate ecological indices for species, males and females (Gamito and Furdato, 2009).

\section{Results}

\section{Overall tick infestation}

A total number of 262 ticks were collected between Spring (May) and Summer (June, July, and August) 2020 from 70 cattle, 196 goats and 182 sheep at the municipal slaughterhouse of Tadjenanet, in the province of Mila in north-eastern Algeria. These ticks belong to 2 genera, namely Rhipicephalus spp. $(\mathrm{n}=$ 209; 79.77\%) and Hyalomma spp. $(\mathrm{n}=53 ; 20.23 \%)$ and 10 species namely, Rh. (Boophilus) annulatus ( $\mathrm{n}$ $=8 ; 3.05 \%)$, Rh. bursa $(\mathrm{n}=108 ; 41.22 \%)$, Rh. sanguineus $(\mathrm{n}=91 ; 34.73 \%)$, Hy. anatolicum $(\mathrm{n}=4 ; 1.53 \%)$, Hy. excavatum $(\mathrm{n}=1 ; 0.38 \%)$, Hy. impeltatum $(\mathrm{n}=1 ; 0.38 \%)$, Hy. Iusitanicum $(\mathrm{n}=5 ; 1.91 \%)$, Hy. marginatum $(\mathrm{n}=8 ; 3.05 \%)$ and Hy. scupense $(\mathrm{n}=34 ; 12.98 \%)(\mathrm{P}<0.001)$ (Table 1$)$. Rh. bursa and $R h$. sanguineus were present during the study period. Animals examined in August showed a particular infestation pattern. Indeed, Rh. sanguineus was only present in sheep, whereas $H y$. excavatum and $H y$. impeltatum were only found in goats. Most of the Hyallomma species (4 species) were collected from cattle (Table 1). Of the 448 animals examined in this study, 67 were infested. In this study, no statistically significant association was observed between tick prevalence and male and female animals, however, a statistically significant association was observed between the intensity of infestation and month, and the site of attachment compared to previous months was higher in the ears than in other locations (Table 2). In addition, no statistically significant association was observed between the intensity of tick infestation by animal category (cattle, sheep, and goats) (Table 1). 
For prevalence, were not significant $(p>0.05)$. For intensity, it was significant $(p<0.05)$. The latter dramatically affects the Shannon index $(H=1.43 ; \mathrm{Hmax}=2.19$ bits), in this locality in north-eastern Algeria: $\mathrm{H}=1.43$ bits; $\mathrm{S}=10$ species, the Shannon index decreases with the decrease in the number of species: Female $\mathrm{S}=6$ species; $\mathrm{H}=1.29$ bits and in the male $\mathrm{S}=8$ species; $\mathrm{H}=1.39$ bits. Equitability indicates that individuals in the community are not distributed equitably among these species. In addition, more than $41 \%$ of the individuals belong to a single species; $R h$. bursa (species; $\mathrm{E}=0.62$ ) and females where more than $42 \%$ belong to Rhipicephalus bursa (females; $\mathrm{E}=0.72$ ), and males where more than $44 \%$ belong to Rhipicephalus bursa (males; $\mathrm{E}=0.66$ ), respectively (Table 3 ).

\section{Infestation rate of Rhipicephalus ticks}

In May, goats are more infested than sheep. This situation changes in July, when all animals are infested, and the same is true for the month of July, whereas in August only sheep are infested at a very low rate. $\mathrm{Rh}$. bursa has been widespread and the prevalence of tick infestation for Rh. bursa peaks in June, while Rh. sanguineus peaks in May. Rh (Boophilus) annulatus and Rh. turanicus were absent in June and August. The average intensity was 3 ticks per animal, the highest values were observed in May, especially in goats. More than half of the livestock (12 out of 17 cows) were infested by the Rh. bursa, with an intensity of 8 ticks per cow in the sub-humid zone (Guelma, in the north-eastern region of Algeria). In the semi-arid zone (Mila, north-eastern Algeria), the highest prevalence was related to the Rh. bursa (92.85\%) with an intensity of 5 ticks per cow. The results show that the third species of the genus Rhipicephalus is $R h$. sanguineus. Absent in the sub-humid zone (Guelma), it has a prevalence equal to $14.28 \%$ with an intensity of 8 ticks per cow. This result (9.52\%) is higher than the one recorded in the humid zone (Jijel) with 1 tick per cow (Table 2).

\section{Hyalomma ticks}

Four species of Hyalloma; Hy. marginatum Hy. lusitanicum, Hy. anatolicum and Hy. scupense were found infesting cattle. Hy. excavatum and Hy. impletatum were found in goats only in June. Only one $\mathrm{Hy}$. scupense specimens was present infesting the cattle in July, with an intensity of 0.5 ticks per cow (Table 2).

\section{Tick infestation rate according to site of attachment}

262 ticks collected from different parts of the body of the animals, most ticks were found to attach to the entire body surface, mainly on the ears (61.36\%), testicles $(22.73 \%)$, anus $(9.09 \%)$, back, eyes and mammals (2.27\%) (Table 3$)$.

\section{Discussion}

This study aimed to identify ticks between May and August 2020 in the municipal slaughterhouse of Tadjenanet Mila, in north-eastern Algeria. A total of 262 ticks were collected from 448 animals, ten species were identified, namely, Rhipicephalus (Boophilus) annulatus, Rhipicephalus bursa, 
Rhipicephalus sanguineus, Rhipicephalus turanicus, Hyalomma marginatum, Hyalomma excavtum, Hyalomma scupense, Hyalomma lusitanicum, Hyalomma impeltatum and Hyalomma anatolicum. This is the first time to report the presence of Hyalomma excavtum and Hyalomma impeltatum in the region of Mila and Hyalomma impeltatum for the second time in north-eastern Algeria (Derradj et al., 2019; Data not published).

The results obtained in this study are in good agreement with the results obtained by Benchikh Elfegoun et al. in 2013. In the semi-arid region (Mila), seven species of ticks were also later described by Benchikh El-Fegoun et al. in 2014, noting the high prevalence for Rh. bursa 214 (71.1\%). This tick is the vector of Bovine babesiosis in Babesia bigemina and B. bovis (Bourdeau, 1993). It was detected from June 2002 to May 2003, in Taher region (9.35\%) (Benchikh El-Fegoun et al., 2007), and in Constantine at a rate of 122 (22.8) (Benchikh ElFegoun et al., 2019). Rh. bursa is a cosmopolitan tick; in Morocco this tick was found at a rate of 1326 (12.89\%) (Laamri et al., 2012). Rh. (Boophilus) annulatus (3.43\%) is the vector of Babesia bigemina and B. bovis in cattle. It was described in 2011 in Côte d'Ivoire (Ivory Coast) (less than 5\%) (Madder et al., 2011).

Rh. sanguineus, a tick rarely found in cattle, it was recorded in Mila (rate of 91) (34.73\%). Their presence, reported at a rate of $26.6 \%$ (Benchikh Elfegoun et al., 2019), was also identified in Spain at a rate of $0.5 \%$ (Toure et al., 2014). In this study, Hy. scupense, a tick that transmits several pathogens such as Theileria annulata, was identified in arid regions, particularly in the north. These results are consistent with those of Gharbi et al. (2013; 2014), Benchikh El-Fegoun et al. (2018; 2019), Boutaleb (1982), and Yousfi-Monod (1986).

Hyalomma excavum was also identified in our study; it is a tick that can host Theileria annulata. This tick was identified as a vector of Theileria lestoquardi in Tunisia by Rjeibi et al. in 2016.

Hyalomma anatolicum was reported to be found in Iran at a rate of 38.83\% (Biglari et al., 2018). In Iraq, 50 ticks collected from cows were characterised by PCR, the result showed the presence of Hyalomma anatolicum (Al-Fatlawi et al., 2018). In Turkey, a study by Aktas showed that 2895 ticks were identified as Hyalomma anatolicum and that $11.3 \%$ of male ticks and $22.4 \%$ of female ticks were positive in Theileria (Aktas et al., 2004). Hy impeltatum was found in the sub-humid region (Guelma) (Derradj et al., 2019). For this tick, it is important to note that this is the second report from north-eastern Algeria. In Tunisia, Bouattour described it in 1999 in arid and desert areas. It was also identified in Sudan by Um El Hassan Mustafa in 1983 as the vector of Theileria annulata. Hy impeltatum is mainly present in Mediterranean regions, steppes and deserts (Walker et al., 2003).

Hyalomma marginatum and Hyalomma lusitanicum are widespread in the Mediterranean climate (Walker, 2003). Hyalomma marginatum was already described by Benchikh Elfegoun in 2019 at 11\%, and $3.9 \%$ for Hy. Iusitanicum. The results show that it is abundant in the humid region (Jijel), but a few specimens were collected in both the sub-humid (Guelma) and semi-arid (Mila) regions by Derradj et al. in 2019; data not published). Their infestation prevalences are higher in the humid region (Jijel) and the sub- 
humid region (Guelma). Both species were reported in previous studies by Benchikh El-fegoun et al. (2007; 2014; 2019).

Rhipicephalus turanicus is a tick of sub-Saharan Africa, concentrated in sheep and horses, in North-Africa infests goats (Walker et al., 2003). This tick species known as vector of Rickettsia massiliae (Matsumoto et al., 2005) and Coxiella sp (Lalzar et al., 2012).

\section{Conclusion}

This study aimed to determine and compare the prevalence and intensity of infestations on domestic animals in the municipal slaughterhouse of Tadjenanet, with an analysis of ecological indices in the province of Mila, in the north-east of Algeria. The study provided new information on hard ticks, the infestation rates of domestic animals that determine their distribution in north-eastern Algeria. The results suggest that this approach could also be useful to help control programmes in this region.

\section{Declarations}

-No approval of research ethics committees was required to accomplish the goals of this study because experimental work was conducted with an unregulated invertebrate species.

-Funding: The current research received a grant from Arthropods Biosystematics and Ecology laboratory, Frères Mentouri - Constantine 1 University, Constantine, Algeria.

-Conflicts of interest: No potential conflict of interest was reported by the authors.

-Code availability: 'Not applicable'.

-Authors' Contributions - DL collected ticks and conceived the manuscript, KK planned the research and identified tick species.

-Ethics approval : 'Not applicable'.

-Consent to participate: 'Not applicable'.

-Consent for publication: 'Not applicable'.

\section{References}

1. Aktas M, Dumanli N, Angin M. 2004. Cattle infestation by Hyalomma ticks and prevalence of Theileria in Hyalomma species in the east of Turkey. Veterinary Parasitology. 119(1):1-8

2. Al-Fatlawi M, Ali M, Albayati H. 2018. Morphological and phylogenetic study of Hyalomma anatolicum in Al-Najaf, Iraq. Iraqi Journal of Veterinary Sciences. 32(2):261-266 
3. Benchikh-Elfegoun M, Benakhla A, Bentounsi B, Bouattour A, Piarroux R (2007) Identification et cinétique saisonnière des tiques parasites des bovins dans la région de Taher (Jijel) Algérie. Ann Med Vet 151:209-214

4. Benchikh-Elfegoun M, Gharbi M, Djebir S, Kohil K (2013) Dynamique d'activité saisonnière des tiques ixodidés parasites des bovins dans deux étages bioclimatiques du nord-est alge'rien. Rev Elev Med Vet 66:117-122

5. Benchikh-Elfegoun M, Gharbi M, Merzekani Z, Kohil K (2018) Piroplasmoses bovines dans les provinces de Skikda et d'Oum El Bouaghi (nord-est de l'Algérie): étude épidémiologique et estimation des pertes de production laitiére. Rev Elev Med Vet 70:105-110

6. Benchikh-Elfegoun B, Kohil K, Gharbi M, Afoutni L, Benachour ML (2019) cinétique d'infestation par les tiques des bovins de la région subhumide de Constantine en Algérie. Rev Elev Med Vet 72:41-45

7. Biglari P, Bakhshi H, Chinikar S, Belqeiszadeh H, Ghaffari M, Javaherizadeh S, Faghihi F, Telmadarraiy Z. 2018. Hyalomma anatolicum as the main infesting tick in an important livestock-rearing region, central area of Iran. Iranian journal of public health. 47(5):742

8. Bourdeau, P. (1993). Canine babesiasis (Babesia canis). Helminthoses et Protozooses des Carnivores Domestiques.

9. Boutaleb K. 1982. Les connaissances actuelles sur les tiques du bétail en Algérie. [dissertation]. Constantine: University of Constantine. [Current knowledge on livestock ticks in Algeria]. French.

10. Bowman, A. S., Ball, A., \& Sauer, J. R. (2008). Tick salivary glands: The physiology of tick water balance and their role in pathogen trafficking and transmission. Ticks: biology, disease and control, 73-91.

11. Bouattour A (2001) 'Les tiques de Tunisie: Rôle de Hyalomma detritum dans la transmission de Theileria annulata. PhD thesis Faculty of Sciences, Tunis, p 247

12. Boulkaboul A (2003) Parasitisme des tiques (Ixodidae) des bovins à Tiaret, Algérie. Revue d'élevage et de médecine vétérinaire des pays tropicaux 56:157-162.

13. Bush, A. O., Lafferty, K. D., Lotz, J. M., \& Shostak, A. W. (1997). Parasitology meets ecology on its own terms: Margolis et al. revisited. The Journal of parasitology, 575-583.

14. Derradj, L and Kohil. K (2020). Identification and incidence of hard tick species during summer season 2019 in Jijel Province (northeastern Algeria). Journal of Parasitic Diseases, 1-7.

15. Gamito, S,. Furtado, R,. 2009. Feeding diversity in macroinvertebrate communities: a contribution to estimate the ecological status in shallow waters. Ecological Indicators 9, 1009-1019.

16. Gharbi M, Hayouni ME, Sassi L, Dridi W, Darghouth MA. 2013. Hyalomma scupense (Acari, Ixodidae) in northeast Tunisia: seasonal population dynamics of nymphs and adults on field cattle. Parasite. 20.

17. Gharbi M, Darghouth MA. 2014. A review of Hyalomma scupense (Acari, Ixodidae) in the Maghreb region: from biology to control. Parasite. 21 
18. Laamari, A., Kharrim, K. E., Mrifag, R., Boukbal, M., \& Belghyti, D. (2012). Dynamique des populations de tiques parasites des bovins de la région du Gharb au Maroc. Revue d'élevage et de médecine vétérinaire des pays tropicaux, 65(3-4), 57-62.

19. Lalzar, I., Harrus, S., Mumcuoglu, K. Y., \& Gottlieb, Y. (2012). Composition and seasonal variation of Rhipicephalus turanicus and Rhipicephalus sanguineus bacterial communities. Applied and environmental microbiology, 78(12), 4110-4116.

20. Madder, M., Thys, E., Achi, L., Touré, A., \& De Deken, R. (2011). Rhipicephalus (Boophilus) microplus: a most successful invasive tick species in West-Africa. Experimental and Applied Acarology, 53(2), 139-145.

21. Matsumoto, K., Ogawa, M., Brouqui, P., Raoult, D., \& Parola, P. (2005). Transmission of Rickettsia massiliae in the tick, Rhipicephalus turanicus. Medical and veterinary entomology, 19(3), 263-270.

22. Parola, P., \& Raoult, D. (2001). Ticks and tickborne bacterial diseases in humans: an emerging infectious threat. Clinical infectious diseases, 32(6), 897-928.

23. Rjeibi, M. R., Darghouth, M. A., Rekik, M., Amor, B., Sassi, L., \& Gharbi, M. (2016). First molecular identification and genetic characterization of Theileria lestoquardi in sheep of the Maghreb region. Transboundary and Emerging Diseases, 63(3), 278-284.

24. Schwartz D. 1993. Méthodes statistiques à l'usage des médecins et des biologistes [Statistical methods for physicians and biologists. 3rd ed. Flammarion: Paris, France]. 3eme éd. Paris: Flammarion. French

25. Touré A, Diaha CA, Sylla I, Kouakou K (2014) Récente recomposition des populations de tiques prévalent en Côte d'Ivoire. Int J Biol Chem Sci 8(2):566-578

26. Walker, A. R. (2003). Ticks of domestic animals in Africa: a guide to identification of species (pp. 3210). Edinburgh: Bioscience Reports.

27. Yousfi-Monod R, Aeschlimann A (1986) Recherches sur les tiques (Acarina: Ixodidae), parasites de bovide's dans l'ouest Alge'rien. Ann Parasitol Hum Comp 61:341-435

\section{Tables}


Table 1. prevalence and intensity of ticks of domestic animals in Tadjenanet, Mila, north-eastern Algeria

\begin{tabular}{|c|c|c|c|c|c|c|c|c|c|c|c|c|c|c|c|c|c|c|c|c|c|}
\hline \multirow{3}{*}{$\begin{array}{l}\text { Animals category } \\
\text { Species Animals sex }\end{array}$} & \multirow{3}{*}{$\begin{array}{c}\text { Cattle } \\
\text { M }\end{array}$} & \multicolumn{4}{|c|}{ May } & \multicolumn{5}{|c|}{ June } & \multicolumn{5}{|c|}{ Jully } & \multicolumn{5}{|c|}{ August } & \multirow{3}{*}{ Species } \\
\hline & & \multicolumn{2}{|c|}{ Goat } & \multicolumn{2}{|c|}{ Sheep } & \multirow{2}{*}{$\begin{array}{c}\text { Cattle } \\
\text { M }\end{array}$} & \multicolumn{2}{|c|}{ Goat } & \multicolumn{2}{|c|}{ Sheep } & \multirow{2}{*}{$\begin{array}{c}\text { Cattle } \\
\text { M }\end{array}$} & \multicolumn{2}{|c|}{ Goat } & \multicolumn{2}{|c|}{ Sheep } & \multirow{2}{*}{$\begin{array}{c}\text { Cattle } \\
\text { M }\end{array}$} & \multicolumn{2}{|c|}{ Goat } & \multicolumn{2}{|c|}{ Sheep } & \\
\hline & & M & $\mathbf{F}$ & M & $\mathbf{F}$ & & M & F & $\mathbf{M}$ & $\mathbf{F}$ & & $\mathbf{M}$ & $\mathbf{F}$ & M & F & & $\mathbf{M}$ & $\mathbf{F}$ & $\mathbf{M}$ & $\mathbf{F}$ & \\
\hline Rh. annulatus & 0 & 1 & 1 & 0 & 0 & 0 & 0 & 0 & 0 & 0 & 6 & 1 & 0 & 0 & 0 & 0 & 0 & 0 & 0 & 0 & 9 \\
\hline Rh.bursa & 0 & 14 & 14 & 6 & 0 & 5 & 35 & 4 & 4 & 2 & 0 & 4 & 6 & 11 & 1 & 0 & 0 & 0 & 0 & 1 & 107 \\
\hline Rh. turanicus & 0 & 2 & 0 & 0 & 0 & 0 & 0 & 0 & 0 & 0 & 0 & 0 & 0 & 0 & 0 & 0 & 0 & 0 & 0 & 0 & 2 \\
\hline Rh.sanguineus & 0 & 38 & 5 & 9 & 0 & 9 & 9 & 3 & 1 & 9 & 0 & 0 & 1 & 5 & 1 & 0 & 0 & 0 & 0 & 1 & 91 \\
\hline Hy. anatolicum & 0 & 0 & 0 & 0 & 0 & 4 & 0 & 0 & 0 & 0 & 0 & 0 & 0 & 0 & 0 & 0 & 0 & 0 & 0 & 0 & 4 \\
\hline Hy.excavatum & 0 & 0 & 0 & 0 & 0 & 0 & 0 & 1 & 0 & 0 & 0 & 0 & 0 & 0 & 0 & 0 & 0 & 0 & 0 & 0 & 1 \\
\hline Hy.impeltatum & 0 & 0 & 0 & 0 & 0 & 0 & 1 & 0 & 0 & 0 & 0 & 0 & 0 & 0 & 0 & 0 & 0 & 0 & 0 & 0 & 1 \\
\hline Hy.lusitanicum & 0 & 0 & 0 & 0 & 0 & 5 & 0 & 0 & 0 & 0 & 0 & 0 & 0 & 0 & 0 & 0 & 0 & 0 & 0 & 0 & 5 \\
\hline Hy.marginatum & 0 & 0 & 0 & 0 & 0 & 8 & 0 & 0 & 0 & 0 & 0 & 0 & 0 & 0 & 0 & 0 & 0 & 0 & 0 & 0 & 8 \\
\hline Hy. scupense & 0 & 0 & 0 & 0 & 0 & 32 & 0 & 0 & 0 & 0 & 2 & 0 & 0 & 0 & 0 & 0 & 0 & 0 & 0 & 0 & 34 \\
\hline Tick number & 0 & 55 & 20 & 15 & 0 & 63 & 45 & 8 & 5 & 11 & 8 & 5 & 7 & 16 & 2 & 0 & 0 & 0 & 0 & 2 & 262 \\
\hline Animals examined & 15 & 37 & 34 & 18 & 14 & 20 & 37 & 29 & 15 & 6 & 19 & 29 & 20 & 55 & 9 & 16 & 5 & 5 & 40 & 25 & 448 \\
\hline Animals infested & 0 & 8 & 3 & 3 & 0 & 7 & 9 & 6 & 3 & 6 & 4 & 3 & 2 & 9 & 2 & 0 & 0 & 0 & 0 & 2 & 67 \\
\hline Prevalence \% & 0 & 21.62 & 8.82 & 16.67 & 0 & 35 & 24.32 & 20.69 & 20 & 100 & 21.05 & 10.34 & 10 & 16.36 & 22.22 & 0 & 0 & 0 & 0 & 8 & 14.96 \\
\hline Intensity (ticks/animal) & 0 & 6.88 & 6.67 & 5 & 0 & 9 & 5 & 1.33 & 1.67 & 1.83 & 2.00 & 1.67 & 3.5 & 1.78 & 1 & 0 & 0 & 0 & 0 & 1 & 3.91 \\
\hline
\end{tabular}

\section{Table 2. Prevalence of ticks with respect to site of attachment on cattle.}

\begin{tabular}{lllllll}
\hline & Ears & Eyes & Testicles & Anus & Back & Mammals \\
\hline May & 5 & 0 & 0 & 1 & 0 & 0 \\
June & 12 & 0 & 7 & 2 & 1 & 0 \\
Jully & 8 & 1 & 3 & 1 & 0 & 1 \\
August & 2 & 0 & 0 & 0 & 0 & 0 \\
\hline
\end{tabular}

Table 3. Ecological indexes of hard tick species in domestic animals from Tadjenanet, Mila province, northeast Algeria.

\begin{tabular}{ccccccc} 
& Taxa & Individuals & Dominance & Simpson & Shannon & Equitability \\
\cline { 2 - 7 } Species & 10 & 262 & 0,30 & 0,69 & 1,43 & 0,62 \\
Females & 6 & 95 & 0,32 & 0,67 & 1,29 & 0,72 \\
Males & 8 & 167 & 0,31 & 0,68 & 1,39 & 0,66 \\
\hline
\end{tabular}

Figures 


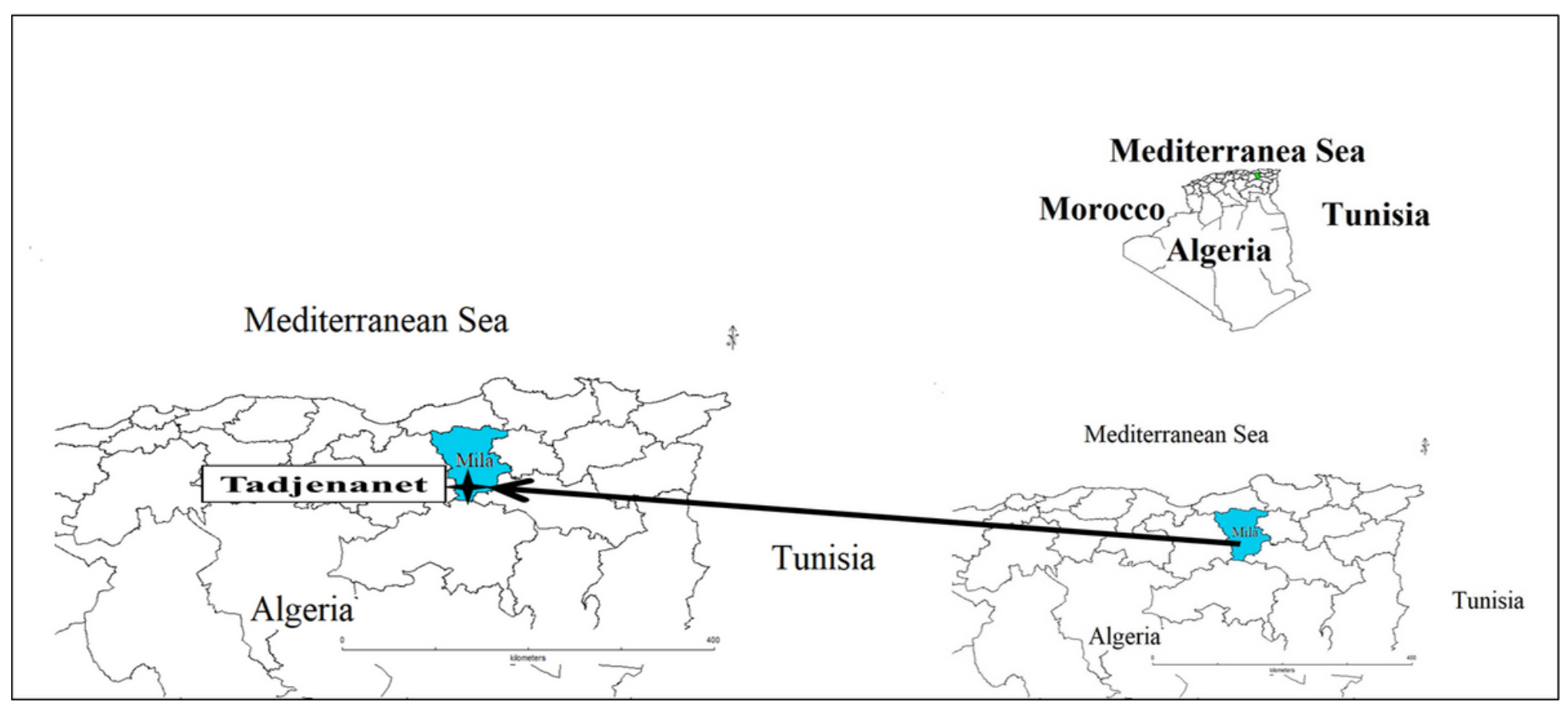

\section{Figure 1}

The geographical location of Tadjenanet, Mila Province, northeast Algeria 